\title{
PENINGKATAN AKTIVITAS DAN HASIL BELAJAR PKN DENGAN PEMBELAJARAN KOOPERATIF TIPE JIGSAW DI KELAS 8C SMP NEGERI 3 BERBAH
}

\author{
Sunarta \\ SMP N 3 Berbah \\ tasunar@yahoo.com
}

\begin{abstract}
Classroom Action Research was conducted in class VIII C SMP Negeri 3 Berbah Academic Year 2013/2014 by using Jigsaw cooperative learning approach. This study aims to implement cooperative learning Jigsaw to improve the activity and learning outcomes of students in the subject of Citizenship Education. The method used in this study is a qualitative descriptive analysis. The results of this study indicate that prior to the implementation of the action no activity learners are categorized very active, the active category $5(22.73 \%)$, fairly active $6(27.27 \%)$ and less active $11(50.00 \%)$. After the first cycle are very active category 5 (27.27\%), the active category 11 (50.00\%), quite active 4 (18.18\%) and less active 1 (4.55). And after the second cycle which is very active category $7(31.82 \%)$, the active category 9 (40.91\%), quite active 5 $(22.73 \%)$ and less active $2(09,09 \%)$ ). When viewed in the development of mastery learning it before action 9 learners otherwise completed (40.91\%), following which the first cycle were 17 (77.27\%) students who otherwise completed and after the second cycle students who achieve mastery learning 19 learners (86.36\%). During the implementation of the action has been an increase in both, the level of activity and learning outcomes of students. Student activity levels increased along with the lessons learned in the initial group of experts and grouped. With increasing activity of the learner cognitive structure and his memory be better study results also increased
\end{abstract}

Keywords: learning activities, learning outcomes, cooperative learning, Jigsaw

\section{PENDAHULUAN}

Pendidikan Kewarganegaraan (PKn) merupakan mata pelajaran yang bertugas membentuk warga negara yang baik, warga negara yang sadar akan hak dan kewajibannya. Dengan sadar akan hak dan kewajibannya maka seseorang warga negara diharapkan menjadi kritis, partisipasif dan bertanggungjawab. Namun dalam kenyataannya, tingkat keberhasilan Pendidikan Kewarganegaraan dalam membentuk manusia yang berkualitas sangatlah rendah. Hal ini disebabkan oleh rendahnya aktivitas peserta didik dalam mempelajari Pendidikan Kewarganegaraan, ini dapat dilihat dari prestasi peserta didik yang cenderung biasa-biasa saja. Sebagian peserta didik menganggap bahwa mata pelajaran PKn termasuk mata pelajaran yang membosankan. Hal ini dapat dilihat ketika proses pembelajaran berlangsung, peserta didik kurang perhatian, kurang antusias, kurang respon terhadap pertanyaan, tidak pernah mengajukan pertanyaan, banyak yang belajar hanya ketika ada ulangan, mengerjakan pekerjaan rumah di sekolah serta tidak memiliki motivasi untuk mempelajari dan mencapai prestasi yang tinggi, sehingga nilai rata-rata kelas masih di bawah Kriteria Ketuntasan Minimal (KKM). 
Peserta didik menganggap bahwa Pendidikan Kewarganegaraan adalah pelajaran yang mudah dan tidak penting, terlebih setelah tidak lagi diikutkan dalam Ujian Nasional. Hal ini dapat menimbulkan rendahnya minat, motivasi dan keaktifan serta prestasi peserta didik terhadap pelajaran Pendidikan Kewarganegaraan.

Guru merupakan komponen penting dalam belajar mengajar yang berinteraksi langsung dengan peserta didik. Guru mempunyai peranan yang sangat penting terhadap terciptanya proses pembelajaran yang ditetapkan. Masalah yang dirasakan adalah masih banyaknya guru yang mengalami kesulitan dalam menciptakan pembelajaran yang kondusif bagi peserta didik. Untuk menciptakan suasana belajar yang kondusif, peseta didik sangat dituntut untuk aktif dalam pelaksanaan pembelajaran demi tercapainya tujuan. Aktivitas yang harus dimiliki peserta didik perlu didukung oleh penentuan strategi pembelajaran yang sesuai dengan keadaan peserta didik dan lingkungan sekolah agar bisa diterapkan strategi pembelajaran yang efektif. Keterlibatan peserta didik secara aktif dalam proses belajar yang diharapkan adalah keterlibatan secara mental (intelektual dan emosional) yang dalam berbagai hal disertai aktivitas belajar peserta didik secara fisik sehingga peserta didik betul-betul aktif dalam proses pembelajaran. Keterlibatan secara mental dalam hal ini adalah ketika proses pembelajaran, pikiran, perasaan dan perhatian peserta didik terfokus pada materi yang sedang dipelajari.

Dari permasalahan yang telah dikemukakan, dapat digambarkan bahwa rendahnya aktivitas peserta didik di kelas $8 \mathrm{C}$ SMP Negeri 3 Berbah pada mata pelajaran PKn dikarenakan kurangnya inovasi dalam pembelajaran. Sebagai upaya meningkatkan aktivitas peserta didik, perlu dikembangkan metode pembelajaran yang tepat. Salah satu metode pembelajaran yang banyak melibatkan aktivitas peserta didik adalah metode pembelajaran kooperatif tipe Jigsaw. Pembelajaran kooperatif tipe Jigsaw mendorong siswa aktif dan saling membantu dalam menguasai materi pelajaran, selain itu juga memungkinkan terciptanya kondisi pembelajaran yang variatif, kondusif, dan menyenangkan bagi peserta didik sehingga meningkatkan aktivitas peserta didik dalam belajar bekerja sama dengan teman, berinteraksi dengan guru sehingga pembelajaran PKn dapat berlangsung efektif.

Menurut Skinner (Baharuddin \& Wahyuni, 2010) belajar merupakan adaptasi perilaku yang progresif. Pidarta (2007, p. 197) mengatakan bahwa belajar adalah perubahan tingkah laku yang relatif permanen sebagai hasil pengalaman (bukan hasil perkembangan, pengaruh obat atau kecelakaan) dan bisa melaksanakannya pada pengetahuan lain serta mampu mengomunikasikan kepada orang lain. Sedang menurut Winkel (1989, p. 36) belajar merupakan 'suatu aktivitas mental/psikis, yang berlangsung dalam interaksi aktif dengan lingkungan, yang menghasilkan perubahan-perubahan dalam pengetahuanpemahaman, keterampilan dan nilai-sikap, perubahan itu relatif konstan dan berbekas'. Selain itu, Baharudin (Baharuddin \& Wahyuni, 2010, p. 156) menambahkan bahwa suatu kegiatan belajar memiliki ciri-ciri sebagai berikut.

1) ditandai adanya perubahan tingkah laku,

2) perubahan tingkah laku itu relatif permanen,

3) perubahan tingkah laku tidak segera dapat diamati pada saat proses berlangsung, 
4) perubahan tingkah lak merupakan hasil latihan dan pengalaman,

5) pengalaman itu dapat memberi perubahan perbuatan.

Aktivitas berhubungan dengan kegiatan fisik maupun psikis. Aktivitas fisik berkaitan dengan kegiatan anggota badan, membuat sesuatu, bermain atau bekerja, berpindah tempat, berbicara dan lain sebagainya. Sedang aktivitas psikis berkaitan dengan kegiatan yang melibatkan otak, emosi dan daya jiwa. Menurut Soemanto (1998) (1990:102-107) aktivitas belajar meliputi : a) mendengarkan, b) memandang, c) meraba, membau, mencicipi, mengecap, d) menulis, mencatat, e) membaca, f) membuat ikhtisar, ringkasan dan menggaris bawahi, g) mengamati tabel, diagram, bagan, h) menyusun paper, kertas kerja, i) mengingat, j) berfikir dan k) latihan praktik. Pendapat di atas mengisyaratkan bahwa peserta didik yang aktif dalam pembelajaran secara fisik dan psikis adalah:

1) datang tepat waktu,

2) berbuat untuk memahami materi pelajaran dengan sungguh-sungguh,

3) mendengarkan penjelasan teman, guru,

4) membaca materi pelajaran,

5) menemukan jawaban,

6) menulis /mencatat/membuat laporan,

7) mengonfirmasi penemuan,

8) berusaha menyelesaikan tugas yang diberikan ,

9) mengambil bagian dalam diskusi,

10) mematuhi instruksi-instruksi/aturan main,

11) menghormati orang lain,

12) mengajukan pertanyaan/tanggapan,

13) menjawab pertanyaan,

14) membantu kesulitan teman,

15) terlibat secara emosional dalam pembelajaran.
Pembelajaran kooperatif Jigsaw merupakan salah satu tipe pembelajaran kooperatif yang mendorong peserta didik untuk aktif dan saling membantu dalam menguasai materi pelajaran untuk mencapai prestasi yang maksimal. Peserta didik bekerja dalam tim yang heterogen, baik kepandaian, jenis kelamin, agama, suku maupun ras. Peserta didik diberikan tugas untuk membaca beberapa materi pelajaran dan diberikan "lembar ahli" yang terdiri dari topik-topik yang berbeda yang harus menjadi fokus perhatian masing-masing anggota tim saat mereka membaca.

Setelah semua peserta didik selesai membaca, peserta didik dari tim yang berbeda yang mempunyai fokus topik yang sama bertemu dalam "kelompok ahli "untuk mendiskusikan topik mereka. Para ahli tersebut kemudian kembali kepada tim asal mereka dan secara bergantian mengajari teman satu timnya mengenai topik mereka. Terakhir adalah, peserta didik menerima penilaian yang mencakup seluruh topik. Skor penilaian akan menjadi skor tim, dan anggota dan tim dengan skor terbaik akan mendapatkan penghargaan.

Langkah-langkah pembelajaran kooperatif tipe Jigsaw :

1. Persiapan

a. Menentukan materi untuk dibaca peserta didik.

b. Membuat sebuah lembar ahli, yang mengatakan kepada peserta didik di mana mereka perlu berkonsentrasi saat membaca. Lembar ini berisi topik yang menjadi inti dari unit pembelajaran.

c. Tes penilaian yang berisi pertanyaan.

2. Membagi kelas menjadi kelompok heterogen. 
a. Mendistribusikan teks kepada anggota kelompok

b. Membagi tiap-tiap topik kepada masing-masing anggota

c. Memberi kesempatan kepada peserta didik untuk membaca materi mereka.

d. Waktu 15 menit

3. Diskusi kelompok ahli

a. Peseta didik dengan topik ahli 1 berkumpul bersama dalam satu meja, peserta didik dengan topik ahli 2 berkumpul bersama di meja yang lain dan seterusnya.

b. Berikan kesempatan kelompok ahli untuk bekerja mendiskusikan topiktopik mereka.

c. Waktu 20 menit

4. Laporan tim ahli

a. Para ahli kembali kepada timnya masing-masing untuk mengajari topik mereka kepada teman satu timnya.

b. Jika ada dua tim ahli yang memiliki topik sama, mereka harus presentasi bersama-sama

c. Masing-masing tim ahli diberi waktu 4 menit.

5. Tes
b. Skor masing-masing individu dijumlahkan menjadi skor tim
c. Tim terbaik akan mendapatkan penghargaan tertinggi.

Berdasarkan penjelasan di atas maka model pembelajaran kooperatif tipe Jigsaw memiliki beberapa kelebihan, yaitu:
a. Melatih peserta didik untuk bertanggung jawab secara individu maupun kelompok
b. Melatih peserta didik untuk lebih aktif belajar, memahami materi, mengemukakan pendapat, pikiran

konsep, sehingga masing-masing memberi kontribusi kepada pencapaian tujuan yang lain.

c. Tercipta suasana belajar yang akrab, saling bekerja sama, saling menghargai, dan saling membantu dalam menyelesaikan tugas bersama

d. Kesuksesan salah satu peserta didik akan ditularkan kepada yang lain, tanpa menghalang-halangi kesuksesan orang lain

e. Peserta didik yang berprestasi dalam kelas akan mendapatkan "status sosial tinggi“" sehingga akan lebih dihargai oleh peserta didik lain.

f. Membuat perbedaan menjadi bahan pembelajaran, bukan masalah dalam pembelajaran.

g. Melalui proses menemukan, mendiskusikan, mengajarkan, lebih menjadikan peserta didik menguasai kompetensi yang diharuskan sehingga lebih meningkatkan prestasi belajarnya.

h. Mengembangkan hubungan peserta didik dari latar belakang yang heterogen, sehingga terwujud Bhineka Tunggal Ika

\section{METODE}

Penelitian ini merupakan penelitian tindakan kelas atau Classroom Action Research. Penelitian tindakan kelas adalah penelitian praktis yang dimaksudkan untuk memperbaiki atau meningkatkan mutu pembelajaran di kelas dan upaya perbaikan dengan melaksanakan tindakan untuk mencari jawaban atas permasalahan yang diangkat dari kegiatan tugas sehari-hari di kelas. Tujuan Penelitian Tindakan Kelas (PTK) adalah untuk memperbaiki dan 
meningkatkan praktik pembelajaran di kelas secara berkesinambungan.

Penelitian Tindakan Kelas ini dilakukan dengan kolaboratif dan partisipasif. Artinya dalam melakukan penelitian ini peneliti bekerja sama dengan guru yang mengajar di kelas 8C SMP Negeri 3 Berbah Sleman Yogyakarta. Secara partisipasif bersamasama dengan mitra peneliti akan melaksanakan penelitian ini langkah demi langkah.

Lokasi pelaksanaan Penelitian Tindakan Kelas adalah di SMP Negeri 3 Berbah dengan alamat Jogotiroto, Berbah, Sleman. Sebuah SMP yang berada di pinggiran Kabupaten Sleman tepatnya di perbatasan dengan Kabupaten Bantul yaitu berhimpitan dengan kecamatan Piyungan. Sekolah ini terdiri 4 kelas paralel dengan 288 peserta didik dan berdiri sejak tahun 1996.

Dalam penelitian ini, subjek penelitiannya adalah peserta didik kelas 8C SMP N 3 Berbah yang berjumlah 22 peserta didik. Dipilihnya kelas 8C sebagai objek penelitian dengan pertimbangan sebagai berikut:

1. Keaktifan peserta didiknya dalam mengikuti pembelajaran PKn menurut pengamatan penulis, sangat rendah.

2. Memiliki peserta didik paling heterogen, mulai dari jenis kelamin, agama, dan adanya peseta didik yang tahun sebelumnya tidak naik.

Objek dalam penelitian ini adalah pelaksanaan proses dari model pembelajaran kooperatif tipe Jigsaw pada pembelajaran Pendidikan Kewarganegaraan kelas 8C SMP N 3 Berbah Sleman Yogyakarta Tahun Pelajaran 2013/2014. Penelitian ini diterapkan dalam pokok bahasan Kedaulatan Rakyat.

Penelitian ini direncanakan terdiri dari 2 siklus dan dari setiap siklus terdiri dari perencanaan, pelaksanaan tindakan, observasi dan refleksi. Tiap siklus direncanakan dua kali tatap muka.

Data yang diperoleh dalam penelitian ini adalah berupa lembar observasi dalam proses pembelajaran dan lembar hasil belajar peserta didik. Lembar observasi terdiri dari lembar observasi untuk siswa dan lembar observasi untuk guru yang diambil pada saat terjadinya proses belajar mengajar.

\section{HASIL DAN PEMBAHASAN}

Sebelum melakukan penelitian, peneliti memberi penjelasan bahwa pembelajaran yang akan dilakukan adalah pembelajaran kooperatif, yaitu dengan menggunakan model Jigsaw. Dengan tahapan; pembagian kelompok, pemberian materi dan kartu ahli, belajar secara individual, pembentukan kelompok ahli, diskusi dalam kelompok ahli, kembali kedalam kelompok asal, melalukan presentasi di kelompok, tes, penghitungan nilai kelompok, dan pemberian penghargaan bagi kelompok terbaik. Pembagian kelompok dibentuk oleh peneliti dengan mempertimbangkan ranking prestasi semester satu dan jenis kelamin. Setiap kelompok terdiri dari peserta didik yang memiliki ranking tinggi, sedang dan rendah, serta lakilaki dan perempuan.

Peneliti juga menjelaskan dalam kegiatan pembelajaran setiap kelompok memberi penomoran sendiri sesuai jumlah kelompok, setelah itu diberikan materi yang berbeda untuk dibaca. Kartu ahli yang berisi pertanyaan yang harus dijawab oleh masingmasing anggota kelompok sesuai materi yang telah dibaca. Selanjutnya anggota yang bernomor 1, berkumpul dan berkelompok dengan anggota yang bernomor 1 dari kelompok lain dan membentuk kelompok ahli untuk soal nomor 1, yang kemudian disebut 
tim ahli 1. Anggota bernomor 2 berkumpul dengan anggota bernomor 2 dari kelompok lain dan membentuk kelompok ahli 2, dan seterusnya. Masing-masing kelompok ahli berdiskusi dan mencari jawaban atas permasalahan yang mereka terima. Setelah itu anggota tim ahli kembali ke dalam kelompok semula, kemudian melakukan presentasi secara bergilir di kelompoknya mulai dari anggota tim ahli 1 sampai 5. Setelah Presentasi, bersama guru menyimpulkan pembelajaran, dilanjutkan tes individual. Nilai tes individu dijumlahkan dengan teman dalam kelompok sehingga menjadi nilai kelompok.

Dalam belajar kelompok setiap peserta didik harus berperan aktif mulai dari mendengarkan perintah guru, membaca materi, berdiskusi, presentasi, mendengarkan presentasi teman satu kelompok, dan mengerjakan tes. Peneliti menjelaskan bahwa dengan model Jigsaw ini melatih kemampuan peserta didik untuk sangat aktif dan saling membantu untuk memecahkan masalah bersama, sehingga nantinya akan sangat bermanfaat dalam kehidupan.

Sebelum dilakukan penelitian tindakan dilakukan, peneliti melakukan pengamatan terhadap aktivitas belajar peserta didik. Hasilnya tingkat aktivitas masih didominasi peserta didik yang kurang aktif yaitu 11 peserta didik $(50,00 \%)$, kemudian diikuti pada kategori cukup aktif dicapai oleh 6 peserta didik $(27,27 \%)$, sedang kategori aktif baru dicapai oleh 5 peserta didik $(22,73 \%)$ dan tidak ada peserta didik yang mencapai kategori sangat aktif $(0 \%)$

Sedang hasil belajar peserta didik pada pra siklus, masih didominasi peserta didik dengan hasil belajar kurang baik, yaitu 9 peserta didik $(40,91 \%)$, kemudian diikuti pada kategori cukup baik dicapai oleh 4 peserta didik $(18,18 \%)$, diikuti kategori baik dicapai oleh 7 peseta didik $(31,82 \%)$, namun untuk kategori sangat baik baru dicapai oleh 2 peserta didik $(9,09 \%)$

\section{Deskripsi Siklus I}

Kegiatan siklus I meliputi; perencanaan, pelaksanaan tindakan dan kegiatan penutup. Pada kegiatan perencanaan tindakan ini peneliti mempersiapkan segala sesuatu yang berkaitan dengan pelaksanaan tindakan, antara lain; menyusun RPP, membuat ringkasan materi, membuat kartu ahli, membentuk kelompok, membuat lembar observasi guru, membuat lembar observasi aktivitas peserta didik, membuat soal tes, membuat tabel skor kelompok, menyiapkan penghargaan, mengadakan koordinasi dengan observer, dan menjelaskan kepada peserta didik tentang pembelajaran kooperatif tipe Jigsaw.

Pada tahap pelaksanaan tindakan pada kegiatan inti kelas dibagi menjadi 7 kelompok yaitu kelompok yaitu MPR, KY, DPRD, PRESIDEN, DPR, DPD, dan KPU secara heterogen, dengan masing-masing kelompok beranggotakan 5 peserta didik, dan diberi penomoran 1 sampai 5 untuk masing-masing anggota. Masing-masing kelompok diberi 5 ringkasan materi kepada masing-masing kelompok untuk dibaca selama 10 menit. Membagikan lembar ahli yang berisikan 5 pertanyaan kepada masing-masing kelompok. Setiap anggota kelompok mendapat tugas untuk menjawab pertanyaan sesuai nomor dalam kelompok. Guru memberi aba-aba untuk membentuk kelompok baru yang disebut kelompok ahli, kelompok ahli I, berisikan anggota dari kelompok-kelompok yang bernomor 1, kelompok ahli II berisikan anggota dari kelompok-kelompok yang bernomor 2, dan seterusnya sehingga terbentuk 5 kelompok ahli. Kelompok ahli 
berdiskusi untuk menjawab pertanyaan yang menjadi tanggung jawabnya, menulisnya dalam buku, memahaminya dan berusaha menemukan cara untuk menjelaskan kepada temannya di kelompok asal. Guru berkeliling untuk membimbing jalannya diskusi kelompok ahli. Diskusi dalam kelompok ahli dilakukan 10 menit. Kemudian guru memberi aba-aba kepada kelompok ahli untuk kembali lagi ke dalam kelompok asal. Masing-masing anggota yang sudah berstatus ahli dalam permasalahan yang menjadi tanggung jawabnya, melakukan presentasi di hadapan anggota kelompoknya, sampai semua anggota kelompok memahami semua permasalahan yang menjadi topik pembelajaran pada pertemuan tersebut. Peserta didik bersama dengan guru menyimpulkan materi pembelajaran. Pada tahap akhir atau kegiatan penutup dengan langkah-langkah; guru mengadakan tes, hasil tes dikoreksi silang dan diberi nilai, guru menjumlahkan nilai masingmasing kelompok guru mengumumkan kelompok terbaik dan diberi penghargaan.

Dari kegiatan pengamatan terhadap pembelajaran Pendidikan Kewarganegaraan pada siklus I dengan menggunakan pembelajaran kooperatif tipe Jigsaw diperoleh hasil seperti di bawah ini.

Tabel 1 Aktivitas Peserta Didik Siklus I

\begin{tabular}{llll}
\hline No & Kategori & $\boldsymbol{\Sigma}$ & $\mathbf{\%}$ \\
\hline 1. & Sangat Aktif & 2 & 9,09 \\
2. & Aktif & 11 & 50,00 \\
3. & Cukup Aktif & 3 & 13,64 \\
4. & Kurang Aktif & 6 & 27,27 \\
& Jumlah & $\mathbf{2 2}$ & $\mathbf{1 0 0}$ \\
\hline
\end{tabular}

Sumber: data diolah peneliti, 2016

Pembelajaran

Kewarganegaraan dengan menerapkan pembelajaran kooperatif tipe Jigsaw pada siklus I, tingkat aktivitas peserta didik yang kurang aktif yaitu 6 peserta didik $(27,27 \%)$. Kemudian diikuti pada kategori cukup aktif dicapai oleh 3 peserta didik (13,64\%), diikuti kategori aktif sebanyak 11 peserta didik
$(50,00 \%)$, dan untuk kategori sangat aktif masih dalam kategori rendah karena baru dicapai oleh 2 peserta didik $(9,09 \%)$. Berarti peserta didik yang mencapai ketuntasan dalam aktivitas belajar baru 13 peserta didik atau $50,09 \%$.

Sedangkan hasil tes pada siklus I dapat dilihat pada tabel berikut.

Tabel 2 Hasil Belajar Peserta Didik Siklus I

\begin{tabular}{llcc}
\hline No & Kategori & $\Sigma$ & $\%$ \\
\hline 1. & Sangat Baik & 6 & 27,27 \\
2. & Baik & 11 & 50,00 \\
3. & Cukup Baik & 4 & 18,18 \\
4. & Kurang Baik & 1 & 04,55 \\
& Jumlah & $\mathbf{2 2}$ & $\mathbf{1 0 0 , 0 0}$ \\
\hline
\end{tabular}

Sumber: data diolah peneliti, 2016

Hasil belajar peserta didik pada siklus I, peserta didik yang memperoleh hasil baik dan sangat baik mencapai 17 siswa atau 77,27\%., kemudian diikuti pada kategori cukup baik dicapai oleh 4 peserta didik $(18,18 \%)$, dan kategori kurang baik sebanyak 1 peserta didik $(04,55 \%)$. Data tersebut menunjukkan bahwa hasil belajar pada siklus satu belum mencapai 
ketuntasan klasikal karena baru mencapai $77,27 \%$ yang seharusnya $85 \%$.

Dari pelaksanaan Pembelajaran kooperatif tipe Jigsaw pada siklus I ditemukan permasalahan-permasalahan:

1. Observer kesulitan mengisi lembar observasi untuk peserta didik karena sebagian peserta didik putri badge nama di dada tertutup kerudung.

2. Sebagian besar peserta didik masih raguragu, untuk melakukan presentasi dalam kelompoknya, karena merupakan sesuatu yang baru bagi mereka.

3. Masih ada beberapa anak yang bekerja sama dalam mengerjakan tes.

Dari hasil diskusi dengan observer diperoleh solusi perlu ada perbaikan dalam proses pembelajaran pada siklus II, yaitu :

1. Menyarankan kepada peserta didik putri untuk memperlihatkan nama di dada pada saat kegiatan pembelajaran.

2. Guru meyakinkan peserta didik agar melakukan presentasi dengan sungguhsungguh, agar peserta didik lain dalam kelompoknya memahami materi yang dipresentasikan.

3. Guru mengacak tempat duduk saat tes, agar peserta didik satu kelompok tidak duduk berdekatan, juga dijelaskan pentingnya tes individual untuk mengukur tingkat penguasaan kompetensi masingmasing peserta didik

\section{Deskripsi Siklus II}

Kegiatan siklus II meliputi; perencanaan, pelaksanaan tindakan dan kegiatan penutup. Pada siklus II dilakukan perbaikan dalam kegiatan perencanaan tindakan. Seperti; menyusun RPP perbaikan, membuat ringkasan materi, membuat kartu ahli, membentuk kelompok, membuat soal tes, menyiapkan penghargaan, dan mengadakan koordinasi dengan observer. Kemudian membagi kelompok menjadi 7 kelompok yaitu kelompok MPR, KY, DPRD, PRESIDEN, DPR, DPD, dan KPU secara heterogen, dengan masing- masing kelompok beranggotakan 5 peserta didik, dan diberi penomoran 1 sampai 5 untuk masingmasing anggota, nomor diusahakan berbeda dengan siklus I. Peneliti menegaskan kembali aturan pembelajaran dengan Jigsaw.

Hasil Penelitian pada Siklus II mengenai tingkat aktivitas peserta didik dalam mengikuti pembelajaran siklus II adalah sebagai berikut.

Tabel 3 Aktivitas Peserta Didik Siklus II

\begin{tabular}{llcc}
\hline No & Kategori & $\boldsymbol{\Sigma}$ & $\mathbf{\%}$ \\
\hline 1. & Sangat Aktif & 7 & 31,82 \\
2. & Aktif & 9 & 40,91 \\
3. & Cukup Aktif & 5 & 22,73 \\
4. & Kurang Aktif & 2 & 9,09 \\
& Jumlah & $\mathbf{2 2}$ & $\mathbf{1 0 0}$ \\
\hline
\end{tabular}

Sumber: data diolah peneliti, 2016

Aktivitas belajar sudah didominasi peserta didik dengan kategori sangat aktif yaitu 7 peserta didik (31,82\%), kemudian diikuti kategori aktif dicapai oleh 9 peserta didik $(40,91 \%)$, sedang peserta didik dengan kategori cukup aktif 5 peserta didik $(22,73 \%)$ dan kategori kurang aktif masih terdapat 2 peserta didik $(9,09 \%)$. Berdasarkan data pada tabel tersebut aktivitas belajar yang tergolong sangat baik dan baik telah mencapai $72,73 \%$, yang berarti pada siklus II ini target penelitian telah tercapai. 
Bila dilihat dari sisi Hasil Belajar siklus II, berdasarkan hasil pos tes dapat dilihat pada tabel berikut. Tabel 4 Hasil Belajar Peserta Didik Siklus II

\begin{tabular}{llcc}
\hline No & Kategori & $\boldsymbol{\Sigma}$ & $\%$ \\
\hline 1. & Sangat Baik & 9 & 40,91 \\
2. & Baik & 10 & 45,45 \\
3. & Cukup Baik & 3 & 09,09 \\
4. & Kurang Baik & 0 & 00,00 \\
& Jumlah & $\mathbf{2 2}$ & $\mathbf{1 0 0 , 0 0}$ \\
\hline
\end{tabular}

Berdasar tampilan tabel di atas, hasil belajar PKn sudah mengalami peningkatan yang signifikan. Peserta didik dengan kategori sangat baik mencapai 9 peserta didik (40,91\%), kemudian diikuti kategori baik dicapai oleh 10 peserta didik (45,45\%), sedang peserta didik dengan kategori cukup baik 3 peserta didik $(09,09 \%)$ dan tidak ada yang berkategori kurang baik.
Sumber: data diolah peneliti, 2016

\section{Perbandingan Hasil Belajar dan Aktivitas Peserta Didik}

Bila kita analisis hasil observasi kegiatan pembelajaran dengan Jigsaw, tingkat aktivitas peserta didik dalam mempelajari Kedaulatan Rakyat baik pada pra Siklus, Siklus 1, dan Siklus 2 diperoleh data sebagai berikut.

Tabel 5 : Perbandingan Aktivitas Peserta Didik

\begin{tabular}{llcccccc}
\hline No & Kategori & \multicolumn{2}{c}{ Pra Siklus } & \multicolumn{2}{c}{ Siklus I } & \multicolumn{2}{c}{ Siklus II } \\
\hline & & $\Sigma$ & $\%$ & $\Sigma$ & $\%$ & $\Sigma$ & $\%$ \\
1. & Sangat Aktif & 0 & 0 & 6 & 27,27 & 7 & 31,82 \\
2. & Aktif & 5 & 22,73 & 11 & 50,00 & 9 & 40,91 \\
3. & Cukup Aktif & 6 & 27,27 & 4 & 18,18 & 5 & 22,73 \\
4. & Kurang Aktif & 11 & 50,00 & 1 & 04,55 & 2 & 9,09 \\
& Jumlah & $\mathbf{2 2}$ & $\mathbf{1 0 0 , 0 0}$ & $\mathbf{2 2}$ & $\mathbf{1 0 0 , 0 0}$ & $\mathbf{2 2}$ & $\mathbf{1 0 0 , 0 0}$ \\
\hline & & \multicolumn{4}{c}{ Sumber: data diolah peneliti, 2016 }
\end{tabular}

Berdasar tampilan data tabel di atas, menunjukkan hasil ada peningkatan aktivitas peserta didik setelah mengikuti pembelajaran kooperatif tipe Jigsaw. Hal ini dibuktikan ada kenaikan yang sangat signifikan baik pada pra siklus, siklus I dan siklus II. Kategori sangat aktif mengalami kenaikan 27,27\% (dari 0 ke 6), kategori aktif mengalami kenaikan 04,55\% (dari 6 ke 7), kemudian kategori cukup aktif pada siklus I mengalami kenaikan $27,27 \%$ (dari 5 ke 11), pada siklus II meningkat $04,55 \%$ ( dari 4 ke 5). Kategori kurang aktif mengalami penurunan yang sangat signifikan yaitu $45,45 \%$ pada siklus I (dari 11 ke 1) dan mengalami peningkatan sebesar 04,55\% pada siklus II (dari 1 ke 2). Secara umum aktivitas peserta didik dalam mengikuti pembelajaran PKn dengan Jigsaw mengalami peningkatan bahkan telah berhasil di atas target $(70 \%)$ peserta didik yang sangat aktif dan aktif yaitu sebesar $72,73 \%$. Hasil ini memperkuat pendapat Pidarta (2007) dan Baharudin (2010) bahwa belajar adalah perubahan tingkah laku yang relatif permanen sebagai hasil pengalaman dan mampu mengomunikasikan kepada orang lain dan memberi perubahan perbuatan. Oleh karena itu aktivitas yang telah dilakukan dalam 
pembelajaran PKn dengan Jigsaw mampu meningkatkan kemampuan peserta dalam membentuk pengalaman dan meningkatkan kemampuan berkomunikasi dengan peserta didik lainnya.
Sedangkan hasil belajar peserta didik pra siklus, siklus I dan siklus II dapat dilihat pada tabel berikut ini.

Tabel 8 : Perbandingan Hasi Belajar Peserta Didik

\begin{tabular}{llcccccc}
\hline \multirow{2}{*}{ No } & \multirow{2}{*}{ Kategori } & \multicolumn{2}{c}{ Pra Siklus } & \multicolumn{2}{c}{ Siklus I } & \multicolumn{2}{c}{ Siklus II } \\
& & $\Sigma$ & $\%$ & $\Sigma$ & $\%$ & $\Sigma$ & $\%$ \\
\hline 1. & Sangat Baik & 2 & 9,09 & 6 & 27,27 & 9 & 40,91 \\
2. & Baik & 7 & 31,82 & 11 & 50,00 & 10 & 45,45 \\
3. & Cukup Baik & 4 & 18,18 & 4 & 18,18 & 3 & 09,09 \\
4. & Kurang Baik & 9 & 40,91 & 1 & 04,55 & 0 & 00,00 \\
& Jumlah & 22 & 100,00 & 22 & 100,00 & 22 & 100,00 \\
\hline
\end{tabular}

Terdapat peningkatan hasil belajar peserta didik setelah mengikuti pembelajaran kooperatif tipe Jigsaw. Hal ini dibuktikan ada kenaikan yang sangat signifikan baik pada pra siklus, siklus I dan siklus II. Kategori sangat baik mengalami kenaikan 18,18 \% (dari 2 ke 6) pada siklus 1 dan kenaikan 13,64\% (dari 6 ke 9) pada siklus 2. Kategori baik mengalami kenaikan 18,18\% (dari 7 ke 11) pada siklus 1 , kemudian berkurang 04,55\% (dari 11 ke 10) pada siklus 2. Kemudian kategori cukup baik pada siklus I tidak mengalami perubahan, pada siklus II berkurang 04,55\% (dari 4 ke 3). Sedangkan kategori kurang baik mengalami penurunan yang sangat menyolok yaitu $36,36 \%$ pada siklus I (dari 9 ke 1) dan pada siklus II sudah tidak ada lagi yang mendapat kategori kurang baik. Secara umum hasil belajar PKn telah mencapai ketuntasan belajar klasikal sebesar 86,36\%. Hasil penelitian membuktikan pendapat (1989) bahwa belajar merupakan suatu aktivitas mental/psikis, yang berlangsung dalam interaksi aktif dengan lingkungan, yang menghasilkan perubahan-perubahan dalam pengetahuan-pemahamannya.

\section{SIMPULAN}

Pembelajaran Kooperatif tipe Jigsaw dapat meningkatkan aktivitas dan hasil belajar peserta didik pada mata pelajaran PKn. Aktivitas peserta didik dalam belajar PKn sebelum pelaksanaan tindakan tidak ada yang berkategori sangat aktif, yang berkategori aktif 5(22,73\%), cukup aktif $6(27,27 \%)$ dan kurang aktif $11(50,00 \%)$. Setelah siklus I yang berkategori sangat aktif $5(27,27 \%)$, yang berkategori aktif $11(50,00 \%)$, cukup aktif $4(18,18 \%)$ dan kurang aktif $1(04,55)$. Dan setelah siklus II yang berkategori sangat aktif $7(31,82 \%)$, yang berkategori aktif 9 $(40,91 \%)$, cukup aktif $5(22,73 \%)$ dan kurang aktif $2(09,09 \%))$. Bila dilihat perkembangan ketuntasan belajarnya maka sebelum tindakan 9 peserta didik dinyatakan tuntas $(40,91 \%)$, stelah siklus I sebanyak $17(77,27 \%)$ peserta didik yang dinyatakan tuntas dan setelah siklus II peserta didik yang mencapai ketuntasan belajar 19 peserta didik $(86,36 \%)$.

\section{DAFTAR PUSTAKA}

Baharuddin, H., \& Wahyuni, E. N. (2010). Teori belajar dan pembelajaran. Yogyakarta: Arruz Media. 
Pidarta, M. (2007). Landasan kependidikan: stimulus ilmu pendidikan bercorak Indonesia. Jakarta: Rineka Cipta.
Soemanto, W. (1998). Psikologi pendidikan. Jakarta: Jakarta: PT Rineka Cipta.

Winkel, W. S. (1989). Psikologi pengajaran. Jakarta: PT. Gramedia Pustaka Utama 